\title{
The Case of Coal
}

\section{Lissa L. Roberts and Joppe van Driel}

Coal plays a key role in current debates regarding both the 'Anthropocene' and 'Great Divergence'. Long identified as having fueled the Industrial Revolution, coal has been celebrated and condemned for spurring material progress and productivity, global inequality and environmental degradation. ${ }^{1}$ But what is coal? While the answer might seem straightforward, recognizing that coal's identity as a chemical substance and material resource actually evolved over time, rather than having been a priori essential, can help us better understand the history which has both shaped and been shaped by it. That is to say that the historical identity of coal evolved through a fluid amalgam of material characteristics and applications, knowledge claims, technological capabilities, market transactions and political decisions. ${ }^{2}$ By uncoupling our understanding of the past from an acceptance that materials have an essential identity, we realize that coal-powered industrialization was not historically inevitable; rather it was a complex matter of choice. This recognition, in turn, accentuates the fact that our collective future is also an open matter of choice.

A partial model for considering what this rethinking entails can be found in Timothy Mitchell, Carbon Democracy: Political power in the age of oil. ${ }^{3}$ In the first chapter, Mitchell contrasts the "socio-technical agencies" of coal and oil, which did so much to shape politics since the nineteenth century. Briefly, coal's extraction, transport and use depended on the workers who operated coalmines, ran the railroads and stoked coal-fueled fires. With so many workers concentrated together in locations that were crucial to the growth of industrial

1 See especially E.A. Wrigley, Energy and the English Industrial Revolution (Cambridge: Cambridge University Press, 2010); Alfred Chandler, "Anthracite Coal and the Beginnings of the Industrial Revolution in the United States," Business History Review 46 (1972): 141-181; Kenneth Pomeranz, The Great Divergence: China, Europe and the making of the modern world economy (Princeton, NJ: Princeton University Press, 200o); Will Steffen, Jacques Grinevald, Paul Crutzen and John McNeill, "The Anthropocene: Conceptual and historical perspectives," Philosophical Transactions of the Royal Society A 369 (2011): 842-867.

2 Compare with the treatment of uranium in Gabrielle Hecht, "Africa and the Nuclear World: Labor, occupational health, and the transnational prodution of uranium," Comparative Studies in Society and History $5^{1}$ (2009): 896-926.

3 Timothy Mitchell, Carbon Democracy: Political power in the age of oil (London: Verso, 2011).

(C) LISSA ROBERTS AND JOPPE VAN DRIEL, 2018 | DOI 10.1163/9789004325562_004

This is an open access chapter distributed under the terms of the CC-BY-NC License. 
society, organization and political clout were bound to follow. What finally broke their power, was not only the cooperation between captains of industry and colluding politicians, however, but society's growing dependence on oil. Because of their relative geographical and practical isolation, oil's workforces - those who manned the oilrigs, built the pipelines and crewed on oil tankers - never organized as coalminers and railway workers had. The global nexus of political and economic power thereby shifted and carbon democracy took on the characteristics that continue to haunt us today.

Mitchell's analysis allows him to emphasize how it is that histories of production, distribution and use are inevitably also social, economic and political histories. Missing, however, is a consideration of whether the identities of the substances with which he begins his analysis also have a history. What does it mean, in other words, to speak of 'coal'? Answering this question takes us back to the long eighteenth century, when fossil substances were being increasingly mined and exploited across significant parts of Europe. As demonstrated in this essay, coal's identity and uses were open matters at the time. As the philosopher Annemarie Mol writes, "[O]ntology is not given in the order of things $[\ldots]$ instead ontologies are brought into being, sustained, or allowed to wither away in common, day-to-day, sociomaterial practices." ${ }^{\text {C }}$ Chemists, natural historians, encyclopedists, scientific societies, mine operators, landowners, investors, inventors, policy-makers and law courts all contributed to shaping coal's identity, classification and use. As they deliberated, they could not know that the sum of their efforts would fuel historical development in the way that has been retrospectively explained by binding coal's 'essential' identity to industrialization.

In what follows, the initial openness of coal's identity is examined. The first section examines the categorizations through which encyclopedists, natural historians and chemists sought to define and situate coal in the realm of nature. The second section zooms in on a series of British cases in which coal was regarded as a 'political' substance whose identity could only be resolved through legal deliberation regarding its use. In the third section we shift our attention to France and examine the evolving identity of coal as a 'natural resource. We do so by considering those for whom the opening and governed exploitation of coal mines was integrated with simultaneous efforts to improve the soil and society. In other words, French chemists, entrepreneurs and offi-

4 Annemarie Mol, The Body Multiple: Ontology in medical practice (Raleigh, NC: Duke University Press, 2002), 6, quoted in Lissa Roberts, "Exploring Global History Through the Lens of History of Chemistry: Materials, identities and governance," History of Science 54 (2016): 335-361, on 347 . 
cials regarded coal mining as an element of oeconomic circulation of materials, meant to stimulate agricultural, industrial and social improvement. Coal's identity was, thus, not written in stone from the beginning of time. Rather it evolved during the period under investigation here in a field of historically open possibilities regarding understanding, use and socio-environmental amelioration.

\section{Tentative Taxonomies}

"[T]here is no standard coal $[\ldots]$ the very word itself is a popular term, which has entered into science."

Even today, coal's identity is ambiguous. The product of decayed organic material, it is generally considered together with inorganic minerals and referred to as having fueled a "mineral based energy economy." ${ }^{6}$ It is variously classified scientifically in terms of the sort of plant remains that compose it (humic and sapropelic), its heating value and carbon content level (lignite, sub-bituminous, bituminous and anthracite), and its chemical composition (this varies in virtually every sample because of local conditions). Classification according to chemical composition, unsurprisingly, has changed along with broader developments in analytic chemistry and its instrumentation. Coal's quadripartite division was only adopted internationally in a standardized way in the late 1930s, bringing a degree of stability after centuries of multiple systems and suggestions.

Part of this is traceable to eighteenth-century translations of the Latin term 'regnum lapideum'. While generally translated as 'mineral kingdom' (or similar cognates in other languages), Linnaeus defined this realm to include 'petrae' (simple stones), 'minerae' (composite/heterogenous stones) and 'fossilia' (aggregate mixts containing both decayed animal and vegetable and substances classed as 'minerae'). In the early editions of his Systema Naturae, the class of minerae was further sub-divided into salts and sulfurs, the latter characterized

5 E.A. Newell Arber, The Natural History of Coal (Cambridge: Cambridge University Press, 1911), 6 .

6 The United States government, for example, only began publishing separate production statistics for minerals and fossil fuels, including coal in 1977, following the 1973 oil crisis. See also Cornelia Klein and Anthony Philpotts, Earth Materials: Introduction to mineralogy and petrology (Cambridge: Cambridge University Press, 2013); E.A. Wrigley, Continuity, Chance and Change: The character of the Industrial Revolution in England (Cambridge: Cambridge University Press, 1988). 
by its combustibility and odoriferous quality. Sulfur, in turn, contained four genera, including bitumen, within which the solids asphaltum, gagates, and lithantrax were situated. The thirteenth edition of this widely referenced book included an alternative system developed by the Swedish physician Magnus Bromelius in 1730. This system divided Sulphura into five groups: sulphur, bitumen, petroleum, succinum and lithanthrax, which were translated into English as sulfur, bitumen, petroleum, amber and coal. ${ }^{7}$

But lack of coherence was not confined to natural history systems. Encyclopedias, iconic vehicles of enlightenment, illustrate this. Both Diderot and d'Alembert's Encyclopédie and its 'Protestant' counterpart edited by Fortuné Barthélemy de Félice (two of the Enlightenment's most successful publishing ventures) spread discussions out among a number of articles, including those dedicated to charbon and its subdivision focusing on charbon de terre, in addition to fossile, and houille. ${ }^{8}$ Neither could turning to chemistry textbooks provide clarification. Until the late 1780 s, as Ursula Klein and Wolfgang Lefèvre point out, chemistry textbooks largely organized their classification systems according to perceptible properties (appearance, smell and taste, solubility, combustibility, etc.) and variously divided the 'mineral kingdom' into competing sets of sub-categories. Wilhelm Homberg's taxonomy, for example, employed the categories metals, salts, stones and earths, while Boerhaave classed the same set of substances as metals, salts, sulfur, stones, earths and semi-metals. Johann Christian Wiegleb divided this realm into earthy bodies, metals, salts, waters and inflammable bodies. ${ }^{9}$ Establishing a unitary identity for 'coal' was bound to be a challenge in such a context.

Contemporary authorities nonetheless managed to turn the characteristics of the chemistry of their age to advantageous use. The French surgeon and Académie des sciences librarian Jean François Clément Morand, for example,

7 Carolus Linnaeus, Systema Naturae (Stockholm: Gottfried Kiesewetter, 1740), 6; Carolus Linnaeus, Systema Naturae, thirteenth edition, ed. Johann F. Gmelin (Leipzig: Georg Emanuel Beer, 1793), vol. 3, 17; in english, see Sir Charles Linné, A General System of Nature [...] translated from Gmelin, Fabricus, Willdenow, etc. [...] by William Turton, M.D. (London: Lackington Allen and Co., 1806), 11.

8 Denis Diderot and Jean le Rond d'Alembert, eds., Encyclopédie ou dictionnaire raisonné des sciences, des arts et des métiers (Paris: André le Breton, Michel-Antoine David, Laurent Durand, Antoine-Claude Briasson, 1751-1772); Fortuné Barthélemy de Félice, ed., Encyclopédie ou Dictionnaire universel raisonné des connoissances humaine (Yverdon, 1770-1780); Robert Darnton, The Business of Enlightenment (Cambridge, MA: Harvard University Press, 1979), especially $19 \mathrm{ff}$.

9 Ursula Klein and Wolfgang Lefèvre, Materials in Eighteenth-Century Science: A historical ontology (Cambridge, MA: MIT Press, 2007), 163-164. 
contrasted natural history's 'superficial' multiplication of names and categories with the analytical insights afforded by chemistry in his oft-cited work l'Art d'exploiter les mines de charbon de terre.

[O]f all the productions of nature's three realms, it is this fossil which presents the most singularities and analytical difficulties [...] In order to acquire a just idea of the constituent parts of charbon de terre, it is indispensible to submit samples from as many different lands as possible to chemical analysis. ${ }^{10}$

Sensible and qualitatively oriented chemistry, still closely related to medicine but also increasingly allied to the improvement of both agriculture and manufacture, provided the analytical tools for linking experimentally-revealed characteristics with a growing understanding of material composition and application. Textures, smells, colors and combustibility, uncovered in the laboratory, indicated whether a given sample of charbon de terre was sulfuric, pyritic, acid or alkaline, in addition to the relative amount of phlogiston it contained. In turn, this helped determine the nature of health risks to local miners and possible medical applications. It further indicated which samples represented sources usable for forge work, domestic heating or fertilizing the soil. ${ }^{11}$

Disciplinary skirmishes continued at least through the 1830 s when William Hutton, agent for the Norwich Fire Insurance Company and amateur natural investigator, noted that every variety of this "fossil" he subjected to microscopic examination revealed the presence of "vegetable remains." ${ }^{2}$ Together with the University of London's botany professor John Lindley, he set out his findings and argued for more attention to what he called fossil botany. Like Morand, Hutton and Lindley justified their approach in opposition to natural history.

$[\mathrm{N}]$ either a barren nomenclature, destitute of all attempts at determining the relations that former species bore to those of our own era, nor supposed identifications of species by vague external characters, nor hasty determinations by analogies by means of partial views of structure,

10 Jean François Clément Morand, L'Art d'exploiter les mines de charbon de terre, 4 vols. (Paris: Saillant et Nyon, 1768-1779), vol. 2, 1117, vol. 4, 1384 .

11 Ibid., see e.g. vol. 2, pp. 980, 1143, 1115, 1150-1159, vol. 4, p. 1384 .

12 The vegetable origins of coal had certainly been noted before this. See e.g. John Playfair, Illustrations of the Huttonian Theory of the Earth (Edinburgh: William Creech, 1802), 148-150, where he discusses the views of Buffon, Richard Kirwan and others. 
are sufficient $[\ldots]$ nothing short of a most rigorous examination is likely to serve the ends of science. ${ }^{13}$

The 'science' these authors wished to serve was directed toward understanding the past. The fossil remains of plants found in various subterranean strata provided them with an as-yet underexplored "glimpse of the early history and condition of our Planet, and of the successive races of organized bodies which have existed upon it."14 Chemical inquiry insinuated itself differently in relation to the passage of time. Similarly able to assemble clues about the Earth's past, it was simultaneously poised to suggest possible futures, whether through its application to the promotion of health, the production of new commodities, the improvement of crop yields, or a more general, manipulable understanding of composition and decomposition.

The successful movement of chemical knowledge and processes in and out of the laboratory depended on practical exactitude, but this was not enough to provide a definitive answer to coal's identity. Tentative taxonomies continue to this day and, as a recent study intriguingly argues, it is the element of time that is responsible for coal's ambiguous identity as a chemical substance. Longstanding tests "afford no information whatsoever [...] about the nature of coal," while examining its source history emphasizes locally-situated particularities of character and composition. Perhaps it would be preferable simply, then, to "look to coal as a natural product that is subject to local and regional variations." 15

As the following section indicates, coal's identity remained a pressing issue from the late eighteenth until the mid-nineteenth century, even if - or especially because - the authority of science was insufficient to resolve the question. But if chemistry suggested trajectories of use that might shape coal's otherwise open future, might arguing back from these projected uses provide coal with a clear definition? Crucially this required more than just moving back and forth in time. It also entailed moving from the laboratory to legal courts and legislatures, where evidence was collected and weighed with different measures and identities were decided in a manner that went beyond 'laws of nature' to include those situated at the intersection of the state, society and the market.

13 John Lindley and William Hutton, Fossil Flora of Great Britain (London: James Ridgway, 18311833), v-vi.

14 Ibid.

15 James G. Speight, The Chemistry and Technology of Coal (Boca Raton: Taylor and Francis, 2013), 97 . 


\section{Adjudicating Identities}

The biography of James Hutton (1726-1797) illustrates how these various threads came together in the late eighteenth century. Educated as a physician, Hutton engaged in a broad array of activities including farming, chemical manufacture, canal construction and management, and geology. Coal played a role in many of his endeavors, including his most famous publication The Theory of the Earth. Hutton defined coal as both the product of dead vegetable matter and as a source of subterranean heat, which was responsible for inciting geo-chemical change; it thereby provided active testimony for the cycles that lent nature's oeconomy its dynamic character. ${ }^{16}$ This invited human stewardship of a global system whose ongoing fertility depended on maintaining its dynamic balance. It also invited analysis of coal's own nature and identity, which Hutton viewed as evolving over time. ${ }^{17}$

Hutton's chemical investigations and related reflections led him to believe that coal was composed of phlogiston and either a simple carbonic substance or oily compounds produced by plants. "[T] hough found in every intermediate state," he distinguished two distinct sorts, related to level of "exposure to higher degrees of heat, and to other circumstances favourable to the dissipation of their more volatile and fluid parts." ${ }^{18}$

Of the one kind is that fossil coal which melts or becomes fluid upon receiving heat; of the other, is that species of coal, found both in Wales and Scotland, which is perfectly infusible in the fire, and burns like coaks, without flame or smoak [sic]. The one species abounds in oily matter, the other has been distilled by heat, until it has become a caput mortuum, or perfect coal. ${ }^{19}$

As this passage indicates, the binary nature of 'coaliness' only revealed itself through time. The first coaly substance was fusible and burned with a flame, losing its phlogiston when heated. The second, more "perfect" coal was the residue of longstanding heat and fusion, which left behind a carbonic and combustible sort of phlogiston.

\footnotetext{
16 For multiple meanings of the word 'oeconomy', see the introduction to this volume.

17 Douglas Allchin, "James Hutton and Coal," Cadernos IG/UNICAMP 7 (1997): 167-183.

18 James Hutton, The Theory of the Earth (Transactions of the Royal Society of Edinburgh, vol. I, Part II, 1788), 209-304, on 240.

19 Ibid., p. 241.
} 
Significantly, Hutton's attention had previously been drawn to both the question of maintaining the earth's fertility and the identity of coal in circumstances that were other than purely intellectual. As an owner of farmland, Hutton held active experimental and financial interests in matters of fertility and fertilization, which led him to test the use of coal ash for improving crop yields. ${ }^{20}$ As an investor and manager of the Forth and Clyde Canal in the Scottish lowlands, the financial success of which depended on being able to maximize the amount of goods that passed through it and minimize the duties that had to be paid on them, Hutton also became actively engaged in the question of coal's identity long before he penned his famous Theory.

With the passage of parliamentary legislation that set a higher duty for shipping excavated coal than for its close - but equally ill-defined - relative "culm", Hutton was anxious to set narrow boundaries around the former's identity and thereby lower the charges assessed on the fossil material that passed through the Forth and Clyde Canal. As he wrote in his 1777 pamphlet Considerations on the Nature, Quality and Distinctions of Coal and Culm, the lack of a legally recognized definition made it impossible to distinguish culm - purportedly the predominant fossil substance to pass through the canal - from coal. Neither did recourse to natural distinctions offer an easy solution.

It cannot be in the nature of the fossile [sic] substance that the distinction of coal and culm consists; for in many places of the kingdom, the same seam, stratum, or mine, produces what is esteemed either coal or culm, according as it is in large pieces or broken small; therefore so far as a judgment should be formed in this way, the distinction of coal and culm would appear to consist in nothing but great and small.

On the other hand, it cannot be in the size alone, that culm differs from coal, because the smallest dust of a certain species of coal always pays the duty proper to coal [...] It is therefore evident, that something else [...] must be required in order to distinguish culm from coal; and it will appear reasonable to look for this in the purposes to which those several commodities may be strictly applicable. ${ }^{21}$

20 James Hutton, "Elements of Agriculture," (unpublished manuscript), 117; cited in Jean Jones, "James Hutton's Agricultural Research and his Life as a Farmer," Annals of Science 42 (1985): 573-601, on 589 .

21 James Hutton, Considerations on the Nature, Quality and Distinctions of Coal and Culm (Edinburgh: C. Elliot, and Richardson and Urquhart, 1777), 2-3. 
Of note in this passage is that it moves from speaking of the "nature" of a substance to the applicability of a commodity without any indication that a boundary exists between the two. Hutton was sure that the use to which a commodity could be put "depends truly on the nature of the substance in question," but argued that this was best revealed "from observations that may be made in the actual application of the commodity." ${ }^{22}$ While material identities were thus ascribed to nature by this logic, they were best sought - according to the same reasoning - through an investigation of marketable goods.

Hutton's memoir was matched by ten months of lobbying the Treasury and Board of Customs in London and answered by at least one angry counter-pamphlet. ${ }^{23}$ In the end, Hutton suggested that fraud could easily be prevented and government revenues protected by a simple test that any revenue agent could perform. When the question arose of whether a barge shipment contained culm or coal, the attending agent had only to place a small sample in a crucible and attempt to light it; culm's fusibility would prevent it from sustaining the fire. ${ }^{24}$ The outcome, enshrined in the passage of Parliamentary legislation in December 1777, practically set the identities of culm and coal and prevented the erosion of profits that would have resulted from a refusal to distinguish culm from coal and grant a lower rate of duty for its transport.

As industrial developments created greater possibilities for the exploitation of materials, legislation and litigation were bound to follow. Questions of ownership, transportation, safety, and revenues were aired and answered in legislative assemblies, administrative offices and law courts. As seen in the case just discussed, establishing material identities was a crucial part of the process. And while this expanded the market for chemist-consultants, their involvement neither guaranteed a solution to the problem nor a trustworthy, scientific reputation for them. ${ }^{25}$ Consultants often disagreed with each other

Ibid.

23 Remarks on "Considerations on the Nature, \&c. of Coal and Culm, \&c." By a Friend to the Revenue. Addressed to the Commissioners for managing his Majesty's Customs (London, 1777), cited in The Monthly Review or Literary Journal 58 (1778): 482; For lobbying by Hutton's colleague, see Jean Jones, "James Hutton and the Forth and Clyde Canal," Annals of Science 39 (1982): 255-263, on 263 .

24 Hutton, Considerations, pp. 12-13 (see note 21).

25 Christopher Hamlin, "The City as a Chemical System? The Chemist as Urban Environmental Professional in France and Britain, 1780-1880," Journal of Urban History 33 (2007): 702-28; Joppe van Driel and Lissa Roberts, "Circulating Salts: Chemical governance and the bifurcation of "nature" and "society", Eighteenth-Century Studies 49 (2016): 233-63, esp. 249; J.Z. Fullmer, “Technology, Chemistry, and the Law in Early 19th-century England," Technology and Culture 21 (1980): 1-28; Paul Lucier, "Court and Controversy: Patenting 
for reasons that spanned experimental evidence, training and interested involvement in the case at hand. Science at the bar exposed its practitioners and their disciplines to the fickle hybridity of a world at once material and social. When "nature" was deemed unable to provide acceptable guidelines, recourse was made to precedents of law and use, generously salted with the power of courtroom or parliamentary persuasion. ${ }^{26}$

A celebrated court case, heard in Edinburgh in 1853, brought all these elements together. A landowning couple, Mr \& Mrs William Gillespie of Torbanehill, had leased a parcel of land to James Russel \& Son, coalmasters. The lease granted the Russels the right to exploit "the whole coal, ironstone, ironore, limestone and fireclay (but not to comprehend copper, or any other minerals whatsoever, except those specified) in the lands of Torbanehill." ${ }^{27}$ They leased the land, which adjoined a parcel they were already working, because they assumed that the veins they had uncovered of what came to be called 'Cannel', 'Boghead' or 'Turbanite' coal continued across the properties' boundary. Since it was a key ingredient in the newly burgeoning business of manufacturing paraffin, lubricants and lamp oil, the Russels stood to make a profit. The Gillespies, however, argued that this substance was not a kind of coal, but a mineral - hence, not covered by the lease. If the Russels wanted to exploit it, they should have to sign a new lease with a higher rate that reflected this added value.

More was at stake than the price of land, though. One of the major manufacturers who depended on a reasonably priced supply of this substance was James Young, who owed his position to a patent that explicitly named the ingredient in his process as 'coal.'28 Should the Gillespies win their case, he stood to lose his dominant industrial position; small wonder that he came to the Russels' aid. As the court case unfolded, twenty-eight geologists, mineralogists, chemists and engineers gave testimony on behalf of the Gillespies; forty-one spoke on behalf of the Russels. The judge finally charged the jury to ignore the conflicting scientific evidence in favor of whether Gillespie had included this disputed mineral as coal in the original lease. "[Y]ou are to determine whether it is coal or is not coal," he pronounced, "in the language spoken

science in the nineteenth century," British Journal for the History of Science 29 (1996): 139154 .

26 Compare with José Ramon Bertomeu's essay in this volume.

27 Alexander Watson Lyell, A Full Report of the Trial Before the Lord Justice-General and a Special Jury of the Issues in the Action at the Instance of Mr. and Mrs. Gillespie of Torbanehill (Edinburgh: Bell and Bradfute, 1853), 2.

28 John Butt, James 'Paraffin' Young: Founder of the mineral oil industry (Edinburgh: Scotland's Cultural Heritage, 1983). 
in the missive $[\ldots]$ not $[\ldots]$ in the language of geologists." ${ }^{29}$ After only ten minutes of deliberation, the jury found for the Russels and, implicitly, for Young's continued dominance in this coal's industrial use.

The results were mixed. The Gillespies went away feeling cheated and continued to seek redress through the courts. Individual scientific reputations were publicly attacked, which emphasized the fragility of science's claim to objectivity. Young's victory was shaky and short-lived. The advertised value of this commodity - recently identified through litigation as coal - drew inventive competitors like moths to a flame; and, by the time his patent ran out in 1860 , its value began to be eclipsed by the rise of shale-oil extraction. But the domain of coal's identity had grown, determined by the interpretation of a legal document rather than the authority of science.

\section{A Fertile Fossil}

The connections between coal and industrialization, along with the social and environmental inequalities and degradation they brought in their combined wake, have been seared into our cultural consciousness by novels such as D.H. Lawrence's Sons and Lovers and Women in Love and Emile Zola's Germinal. Coal, in these literary monuments, warmed the homes and lined the financial portfolios of owners as it blackened the short and miserable lives of workers whose families had to fight even for the right to glean the dusty leftovers of shipments sent to stoke the fires of industry. ${ }^{30}$ These processes have been traced forward from the second half of the nineteenth century with great effect, but carrying them back in time risks papering over important developments. Generally overlooked in histories that return to the eighteenth century is a combination of contemporary recognition of coal's various identities and the presence of oeconomic initiatives that incorporated the reclamation of coal fields into visions of socio-environmental improvement. ${ }^{31}$ Focusing on these

29 Watson Lyell, Trial, pp. 236-237 (see note 27).

30 Giulia Pissarello, "Industrialism as "Tragedy of Ugliness": D.H. Lawrence's ecological consciousness," Griseldaonline 10 (2011): 31-42; Sara B. Pritchard, "Mining Land and Labor," Environmental History, 10 (2005): 731-733; Agnes Kneitz, "As if the River was not Meat and Drink to You': Social novels as a means of framing nineteenth-century environmental justice," Interdisciplinary Studies in Literature and Environment 1 (2015): 1-16.

$3^{1} \quad$ Lissa Roberts, ed., Practicing Oeconomy in the Late Eighteenth Century (Special issue of History and Technology 30 (2014): 133-279). For recognition of various identities, see "Catalogue alphabétique des differents charbons de terre," Morand, L'art d'exploiter les mines, vol. 1, pp. 181-195 (see note 10). 
developments is not to deny coal's involvement in industrialization. It is to recall that the historical trajectory along which this involvement unfolded was neither necessary nor inevitable; alternative routes forward were acknowledged and explored.

The Compagnie des Mines d'Anzin, one of France's largest industrial enterprises in the nineteenth century and setting for key scenes in Germinal, illustrates this. Established in 1757, its incorporation document is couched in Enlightenment terms that describe serving the public good as a primary goal. Beyond rhetoric, the company stood out during its first several decades for providing its workers with housing, medical care, education and retirement pensions. ${ }^{32}$ With this in mind, the rest of this section attends to the ways in which coal's multiple identities were intertwined with the projection of alternative historical futures in France during the second half of the long eighteenth century.

Historians usually situate eighteenth-century French coal prospecting between a deforesting past and an industrializing future. However, the fact that other - often more abundant and easier to access- energy sources were available, reminds us that presenting coal as the driver of industrialization imports a teleological perspective into historical interpretation. ${ }^{33}$ Throughout the eighteenth century wood and peat remained the most commonly used fuels in French households and factories, while the energy supplied by animals, humans, wind- and waterpower continued to top the share of fuel in

32 William Henry Hurlbert, France and the Republic (Charleston: BiblioLife, 2007 [189o]), 328; Richard Barker, "French Entrepreneurship During the Restoration: The record of a single firm, the Anzin Mining Company," The Journal of Economic History 21 (1961): 161-178, on 164 .

33 Michael Williams, Deforesting the Earth: From prehistory to global crisis (Chicago: University of Chicago Press, 2003), 171; Andrée Corvol, trans. Richard C. Holbrook, "The Forest," Pierre Nora and David P. Jordan, eds., Rethinking France: Les lieux de mémoire, vol. 2, Space (Chicago: University of Chicago Press, 2006), 109-110; Ian D. Rotherham and David McCallam, "Peat Bogs, Marshes and Fen as Disputed Landscapes in Late Eighteenth-Century France and England," Louise Lyle and David McCallam, eds., Histoires de la Terre: Earth sciences and French culture 1740-1940 (Amsterdam: Rodopi, 2008), 75-88, on 87; Ivan T. Berend, An Economic History of Nineteenth-Century Europe: Diversity and industrialization (Cambridge: Cambridge University Press, 2013), 80, n. 15; The traditional economic narrative nonetheless remains persistent. Prasannan Parthasarathi, Why Europe Grew Rich and Asia Did Not: Global economic divergence, 1600-1850 (Cambridge: Cambridge University Press, 2011), 160; Charles Coulston Gillispie, Science and Polity in France at the End of the Old Regime (New Jersey: Princeton University Press, 1980), 427; Michael Stephen Smith, The Emergence of Modern Business Enterprise in France (Cambridge: Harvard University Press, 2005), 162. 
manufacturing. ${ }^{34}$ The use of coal for fuel did indeed slowly spread in French glassworks, potteries, brickworks and breweries, favored in these manufactures because the fossil burned at higher temperatures than wood or charcoal. ${ }^{35}$ At the same time, eighteenth-century coal enthusiasts also promoted nonindustrial uses. In his previously mentioned L'Art d'exploiter les mines de charbon de terre, Morand drew on an international array of authors to discuss "the different ways of employing coal in manufactories, workshops and households." ${ }^{36}$ Monitored by chemists, Morand explained, the nature and uses of coal proliferated as it was transformed into various states. Using the fossil as fuel in manufactures, in what he referred to as "the governance of fire," was only one option. ${ }^{37}$ When oily, physicians employed it to combat ringworms, abscesses or sexually transmitted diseases, while craftsmen converted it into varnish. When smoky, it attacked scurvy and measles. Painters used coalimpregnated water to produce black and red pencils. Artisans processed hard and spongy coal to plaster vaulted ceilings. In a powdery state of ash, it found employment in cement, dyestuff and glassworks, or as fertilizer. ${ }^{38}$

At mid-eighteenth century, French nobles were especially prominent among those who mobilized their assets to capitalize on the newly discovered coal fields in northern France. ${ }^{39}$ And here, the promise of mining coal for its fertile ash was attractive - accessing the subsoil to bolster soil fertility. Recognizing an analogy with Dutch successes using peat ash for fertilizer, many nobles invested in coal mining to seek local substitutes that would free them from dependence on imported coal ash from Hainault in the Southern Netherlands and wood and peat ash from the Netherlands. ${ }^{40}$ Their efforts were partly trig-

34 Rondo Cameron, "A New View of European Industrialization," The Economic History Review 38 (1985): 1-23.

35 Fernand Braudel, The Wheels of Commerce, trans. Siân Reynolds (Berkeley and Los Angeles: University of California Press, 1992), 328-29.

36 Morand, L'Art d'exploiter, vol. 2, no. 4, pp. 739-1356 (see note 10).

37 Morand, L'Art d'exploiter, vol. 2, p. 1195 (see note 10).

38 Roland de la Platière, "Abrégé historique de l'usage des cendres de tourbes superficielles \& souterreines pour fertiliser les terres en Hainaut \& dans la haute Picardie," Art du Tourbier, in J.E. Bertrand, Descriptions des arts et métiers, faites ou approuvées par Messieurs de l'Académie royale des sciences, nouvelle édition, vol. XIX (Neuchatel: L'Imprimerie de la Société Typographique, 1783), 472-565, on 546.

39 Marc Rouff, Les mines de charbon en France au XvIIIe siècle (Paris: Rieder et Cie, 1922); Reed Geiger, The Anzin Coal Company: Big business in the early stages of the French Industrial Revolution, 1800-1833 (Newark: University of Delaware Press, 1974). 
gered by recent geo-political developments. The War of the Spanish Succession ended in 1713 with new borders that delegated part of Hainault to the Austrian Hapsburgs, including the coal mining areas of Mons and Charleroi. Inhabitants on the French side of the border, long accustomed to securing supplies of wood-, peat- and coal ash via these areas, now faced fees that could be raised at will by foreign rulers. ${ }^{41}$

Noble French landowners, involved in managing vast tracts of arable fields, had a direct interest in relieving this insecure supply of fertilizers. ${ }^{42}$ This led them to invest in coalmines for two reasons. First, coalmines granted access to coal that, when burned for fuel, left fertile ashes - the use of which as fertilizer for arable agriculture was widely documented in agricultural handbooks going back to the late sixteenth century. ${ }^{43}$ Second, in some cases it was possible to mine specially targeted fossils that could be directly manufactured into fertilizers.

This last strategy gained import in 1753, when coal prospectors in Picardy found shallow deposits of a substance that spontaneously combusted. In a report on their discovery, the intendant of the local administrative center (at Soisson, near Laon) noted that "cultivators and laborers" had found a way to control this spontaneous combustion to produce blackish or reddish ashes that "contained salts specific to vegetation." 44 The report soon circulated widely. The intendant communicated the findings to the Inspecteur-général des manufactures de Picardie, who was charged with consulting the central Council of Commerce on new policies. ${ }^{45}$ The Inspecteur appealed to cultivators and land managers across the country, to harness and experiment with the fertile fossils. As such, the report was taken up in Diderot's Encyclopédie in 1766 and included by the agriculturalist, inspector general of the marine and Académie

cultural and industrial improvement, 1750-180o," History and Technology 30 (2014): 177206.

Roland de la Platière, "Abrégé historique," pp. 545-546 (see note 38); P.M. Jones, The Peasantry in the French Revolution (Cambridge: Cambridge University Press, 1988), 15.

42 Ibid., p. 15.

43 See e.g. Johann Coler, Oeconomia oder Hausbuch, 6 vols. (Wittenberg, 1593-16o6); Gervase Markham, Markhams Farwell to Husbandry or, The inriching of all sorts of Barren and Sterile grounds in our Kingdome, to be as fruitfull in all manner of Graine, Pulse, and Grasse, as the best grounds whatsoever (London: Roger Iackson, 1625); Pieter van Ængelen, De Verstandige Hovenier (Doornick; Marcus Willemsz., 1659), Duhamel du Monceau, Éléments d'agriculture, 2 vols. (Paris: Guerin and Delatour, 1762).

44 Charles-Blaise de Méliand, "Houille," Diderot and d'Alembert, Encyclopédie, vol. 8 (1766), pp. 265-68 (see note 8 ).

45 Gillispie, End of the Old Regime, pp. 425-26 (see note 33). 
des sciences member Henri Louis Duhamel du Monceau in his popular Descriptions des arts et métiers - reaching a wide audience of aristocrats and governors. 46

By this time, more than fifty new coalmines, the explicit purpose of which was to mine for these self-combustible fossils, had been listed in the region. (see Table 2.1.) The fertilizers manufactured from their yields circulated as "cendres de charbon de terre", "cendres d'engrais" or "houille d'engrais" (the term houille was the word for coal used in Lorraine and around Liège). Farmers eagerly bought and used them as fertilizer in arable agriculture. To govern these and other coal mining activities, France's royal administration took an intermediary role, reconciling the drive toward 'improvement' with nobles' assets and the know-how of practitioners. As landowners, the noblemen of northern France were entitled to the land's surface, but the crown could lay claim to everything underneath. By a new decree of 1744 the government assumed control over the distribution of mining concessions, reaffirming that a royal permit was required to open a mine. ${ }^{47}$ Officials prioritized noble requests, but only if they kept production going and hired experts to do the job. In this role, the administration stimulated the exploitation of Picardy's coalfield as a natural resource for the domestic production of fertilizers. For example, one nobleman acquired a concession to quarry all the land between the villages of Ham and Laon, including, as the official document read, the property of others who were currently "unable to undertake the exploitation," provided that he would mine for cendres de charbon de terre, consult other ash mining companies and hire proper "gens de l'art" from Flanders. ${ }^{48}$

The strategy worked. Already in 1766, administrative reports cited over 400 farmers using coal-based fertilizers in the region of Aisne in Picardy alone. ${ }^{49}$ Subsequent surveys continued to cite their frequent use throughout northern France until well into the second half of the nineteenth century. ${ }^{50}$ Stabili-

46 Roland de la Platière, "Abrégé historique" (see note 38); Charles-Blaise de Méliand, "Houille," pp. 265-68 (see note 44).

Arrest du conseil d'etat du roy, PORTANT Règlement pour l'exploitation des Mines de Houille ou Charbon de terre. Du 14 Janvier 1744 (Lyon: P. Valfray Fils, 1744).

48 Germain Martin, La grande industrie en France sous le règne de Louis XV (Paris: A. Fontemoing, 1900), 158; Rouff, Mines de charbon, p. 245 (see note 39).

The following is based on the empirical information provided in M. Lenglen, "Etude de quelques particularités relatives à l'Histoire des Engrais," Bulletin des Engrais 10 (1937): 222-24, 257-59, 305-08, 318-20, 353-55, 380-82, 403-06, 449-53. 407-12; J.I. Pierre, Chimie Agricole ou l'agriculture considérée dans ses rapports principaux avec la chimie, fifth edition (Paris: Libraire Agricole, 1863), 489-9o. 
zation of mining, production and use of cendres de charbon de terre, however, was not straightforward. Its difficult history provides further evidence, of widespread engagement with mining coal for fertilizers, of the involvement of chemistry in these endeavors, and of the changing identity of coal in the period around 1800 .

To begin, the new fossils were initially surrounded by much publicity, as newspaper announcements and advertising posters boasted of the fertilizing quality of what was mined - often without regard to the detailed rules for how to convert these fossils into fertilizers. ${ }^{51}$ High promises could backfire, as some farmers soon started reporting on diminishing returns, voicing fears of longterm soil depletion. In his previously mentioned report, the intendant also acknowledged the occasional hesitations, citing local concerns that cendres de charbon de terre might harm the soil by their burning properties, that they would give a bad taste to crops and keep fodders green for too long, against the taste of the cattle. ${ }^{52}$ One prominent physician joined the skeptics, namely Joseph Raulin (1708-1784), royal pensionary and inspector-general of mineral waters. Raulin argued in a published treatise that the self-combustible fossil, when turned into ash, developed a high concentration of vitriolic acid that was harmful to skin and eyes. When used as fertilizer in fodder cultivation, these properties might be communicated to the crops, causing cattle diseases. The mined substances were surely useful, he stressed, but precautions and strict guidelines were required. ${ }^{53}$ Merchants who traded in Dutch wood- and peat ashes, operating close to the border with the Southern Netherlands (near Cambrai), mobilized such arguments to put pressure on local authorities. These, in turn, started circulating warnings on the potential dangers of mined coal ash (as opposed to the ashes retrieved as a byproduct from burning fuel). Meanwhile, at least one northern French municipality communicated a citizen petition to their provincial council with complaints about increased fire risks, recent disease outbreaks and sulfurous fumes damaging fruit trees, all linked to the nearby cendrières where the self-combustible fossils were transformed into fertilizers. Some agricultural societies tried to dismiss these protests on the ground that they were initiated by landowners with a vested interest in obstructing coal excavation on their lands. Others argued that bad experiences were caused by the fraudulent circulation of forged species.

\footnotetext{
$5^{1} \quad$ Lenglen, "Etude" (see note 49).

$5^{2} \quad$ Méliand 1766, "Houille," pp. 267-68 (see note 44).

53 Joseph Raulin, Examen de la houille, considérée comme engrais des terres (Paris: Vincent, 1775).
} 
Meanwhile, chemically trained officials tried to steer ongoing practices in a good direction. They did so by classifying the mined fossils and formulating strict rules for identification and usage, tied to explicated improvement goals. Practicing chemists at the Académie des sciences, such as Jean Hellot and Gabriel Jars, took the lead in developing the administrative organization of both mining and the use of mined substances. ${ }^{54}$ Combining chemical inquiry with diplomacy and political management, both traveled abroad to examine a wide array of mined substances and their organized extraction. In this context, Hellot experimented with cendres de charbon de terre in the small-scale setting of his garden. ${ }^{55}$

Another member of the Académie, Duhamel du Monceau, followed up on these experiments. After chemically analyzing excavated ashy coal substances in his own laboratory retort, Duhamel discussed their simultaneously natural and political attributes in his widely translated Éléments d'Agriculture (1762). ${ }^{56}$ As such, he formulated detailed guidelines for finding, extracting and using cendre de charbon de terre. This particular "caustic earth", he stressed, "announces itself" by leaving an oily film covering any surface waters in its surroundings. ${ }^{57}$ To convert it into fertilizer, it should be watered slightly, mashed and kneaded into cakes of seven inches in diameter, arranged to form conical structures, allowing well-ventilated, slow combustion that should last for up to three days, before being spread over the land in early spring, in a ratio of sixty to eighty pounds per acre.

Similarly, the intendant adopted sensuous chemical classifications in his original report, to summarize ongoing practices and extract rules for ascertaining quality and proper use of mined self-combustible fossils. ${ }^{58}$ He classified the mined fossils as a salty and bituminous type of "fossil coal", verifiable by its sulfurous odor and the way it lit up when placed in the smoldering remains of a fire. Once the odor faded away, it could be used to cultivate grains, vegetables, vines and fodders, or to maintain meadows.

54 Gillispie, End of the Old Regime, pp. 425-429 (see note 33).

55 Ibid, pp. 427-433; Doru Todericu, "Les mines du pays de Liège dans les papiers du savant Français Jean Hellot (1685-1766)," Technologia 6 (1983): 61-68; Méliand, “Houille," p. 266 (see note 44).

$5^{6}$ Duhamel du Monceau, Éléments d'agriculture, vol. 1, pp. 182-186 (see note 43); Idem., trans. Philip Miller, The Elements of Agriculture, 2 vols (London: Vaillant, Durham and Baldwin, 1764), vol. 1,163-166.

57 Duhamel du Monceau, "Cette terre est caustique" [...] "s'annonce", Éléments d'agriculture, vol. 1, p. 183 (see note 43).

$5^{8}$ Lissa Roberts, "The Death of the Sensuous Chemist: The 'new' chemistry and the transformation of sensuous technology," History and Philosophy of Science 26 (1995): 503-529. 
The written reports of chemically trained officials further circulated through a network of agricultural societies. This way, their descriptions of local practices and their chemical assessments were attached to articulated improvement goals. Tellingly, the initiative to establish these societies - some fifteen founded in 1761-1763 - came jointly from the noblemen Louis-François-Henri de Menon, marquis de Turbilly and the controller-general of finance Henri Bertin. The texts that these societies produced suggest that the initiatives to enroll coalmines in soil fertility management should not be understood solely as a response to international politics. Rather, they extend beyond the quest for import substitution to include broader concerns with oeconomy. The largely noble coal entrepreneurs sought to bridge tradition and change, tying productive investment to promotion of publicly beneficial arts and sciences. ${ }^{59}$ On one hand, they sought to maintain feudal customs of landownership and land cultivation in the face of competitors keen to exploit subterranean resources. On the other, they joined an emerging network of self-proclaimed improvers, involving themselves in the formulation of oeconomic norms, values and goals.

For example, in a series of published treatises on cendres de charbon de terre, the baron Léon de Perthuis de Laillevault (1757-1818), member of the Société d'agriculture de Meaux, emphasized that efforts to promote their use first sprang from "the study of morality." ${ }^{00}$ His writings exemplify the prevailing stance among improvers to present the maintenance of both soil fertility and society-wide improvement as a morally informed project, made possible by organized material exchange and chemical inquiry. Such exchange and inquiry were needed to build self-supporting moral communities, they believed, resilient to the vicissitudes of war and international competition. ${ }^{61}$ Having visited several coalmines and farms while garrisoned in northern France as an army engineer, the baron decided to do his part by communicating his experiences, noting the confusion arising from the various terms indiscriminately used by other writers. He distinguished three types of mined earths: peat, brownish, light, mixed with plant materials and extractable from marshes; houille, a pyritic substance, darker, heavier, purer and extractable from strata as deep as

59 Lissa Roberts, "Geographies of Steam: Mapping the entrepreneurial activities of steam engineers in France during the second half of the eighteenth century," History and Technology, 27 (2011): 417-39, 421-423; Geiger, The Anzin Coal Company pp. 14-29 (see note 39); Rouff, Les mines de charbon (see note 39).

6o "L'étude de la Morale", Léon de Perthuis de Laillevault, Expériences et nouvelles observations sur les houilles d'engrais (Paris: Clouiser et Jombert, 1780), 1.

61 Ibid., pp. 1-17, 21, 37 . 
forty feet; and charbon, the darkest, heaviest, purest and deepest. ${ }^{62}$ The baron described various applications of the ashes of houille that he had witnessed, including, beyond fertilization, the treatment of diseased cows with the fumes and waters flowing from cendrières. ${ }^{63}$

Duhamel also linked his chemical assessment of fertile fossils to a more inclusive political program of mixed social and material resource husbandry, centering around agriculture. As the historian Etienne Stockland has argued, his politics should not be seen as deriving from physiocracy, understood as a school of thought that theorized agriculture as the backbone of (national) surplus production. Rather, it was bound to a practice-based form of political oeconomy ${ }^{64}$ Duhamel promoted collaboration together with a hierarchical division of labor, in which landowners would enable trials; magistrates would protect participating tenants; naturalists would generalize local practices; clergymen would instruct their subjects based on published communication; and working farmers would develop insights through practice. ${ }^{65}$ Defining agriculture as both a "science" and a "branch of government," he viewed such collaborative work as forming, "the true basis of commerce" and moral well-being, as it "estranges [inhabitants] from Vice" and spreads "sentiments of probity."66

Agricultural historians mostly remember Duhamel for propagating the work of Jethro Tull (1674-1741), who sought to circumvent manuring by introducing new sowing and ploughing devices. Yet in both his Traité de la culture des terres suivant les principes de M. Tull (6 vols. 1750-1761) and in his Éléments d'agriculture, Duhamel embraced fertilizers as central to his project and advertized mined coal ashes as part of an extensive list of fertilizer production. Tying ash-based fertilization to the promotion of discarded or previously neglected "litter", he called on every citizen to search for similar "hidden treasures." 67 Duhamel organized the search by distinguishing between fertilizers from the mineral kingdom (including mined cendre de charbon de terre, but also "the ashes of the fossil-coal burnt in glass-houses, brew-houses and other manu-

62 Léon de Perthuis de Laillevault, Observations critiques sur un ouvrage intitulé "Examen de la houille, considérée comme Engrais des terres" (Meaux: Charlie, 1777), 5-9.

63 "Lettre de M. le Marquis de Flavigny", Perthuis de Laillevault, Expériences et nouvelles observations, pp. 134-138 (see note 62); Idem., Instruction familière, adressée aux grand et petits cultivateurs, Sur l'usage des Houilles d'engrais, des Tourbes \& de leurs cendres (Paris: Jombert et Clousier, 1781), 34 .

64 Etienne Stockland, "La Guerre aux Insectes': Pest control and agricultural reform in the French Enlightenment," Annals of Science 70 (2013): 435-460.

65 Duhamel du Monceau, Elements of Agriculture, vol. 1, pp. viii, xi-xii (see note 43).

66 Ibid., pp. vi, xiv.

67 Ibid., p. 180. 
factories", "old rubbish of mortar", "rubbish of old walls", etc.) the vegetable kingdom (including "soot of Chimney-sweepers", "saw-dust", "sea-wreck", etc.) and the animal kingdom (including "the offals and cleansings of slaughterhouses", discarded leather "cuttings", "night-soil", etc.). ${ }^{68}$

Assembling a wealth of such discarded materials might have been straightforward, but they had to be carefully processed to take part in the enactment of the desired socio-material order. Duhamel provided rich information on how to carry this out in practice. Organizing his discussion along the two standard modes of contemporary chemical production - the wet and dry way, he noted that "sensible farmers" accumulated their litter in watered holes, then laid it to rot, while the extracted juices in the holes further "served to enrich and rot the fresh litter." 69 Alternatively, farmers stuffed decaying materials into kilns that were specially constructed to allow for slow burning, yielding ashes impregnated with fertile salts. (See Figure 1.) Such discussion was not uncommon among French amateurs. The marquis de Turbilly, patron of the provincial agricultural societies, for example, likewise acknowledged that when preparing "artificial manure [...] if we lack water, we must turn to fire."70

As valued by these writers, the mined fossils thus gained political attributes. When carefully selected and prepared, they could join other resources to maintain self-supporting moral communities. This vision, in turn, translated into expressions of what constituted good 'oeconomy', connected to values of diligence, thrift and avoidance of waste. Duhamel concluded that proper collaborative management prevented the resources embodied in materials, soils and people from being squandered. "Thus, the best advice I can give to good oeconomists, is first to get their plowed lands in proper order, before they think of breaking up wastes."71

While numerous aristocratic enthusiasts experimented with communicated techniques on their own estates, the oeconomic vision of mutually attuned social classes, materials and landscapes to which promoters attached these techniques obviously failed to materialize. But even if a durable interaction between agricultural societies, mostly occupied by local administrators and aristocrats, and practicing farmers was not achieved, the continued engagements with mining and using fertile fossils in northern France shows that individual successes were booked. ${ }^{72}$

\footnotetext{
68 Ibid., pp. 144, 151, 153, 166, 171-174.

69 Ibid., p. 182.

70 Marquis de Turbilly, Memoire sur les défrichemens (Paris: D'Houry, 1760), 122.

71 Duhamel du Monceau, Elements of Agriculture, vol. 1, p. 100 (see note 43).

72 Gillispie, Science and Polity, p. 370 (see note 33).
} 
In the long run, however, these activities became disconnected from the Western-European coal business. During the first half of the nineteenth century, the regional involvement of coal mines in soil fertility management was increasingly overshadowed by the contemporary growth of mechanizing industry. As mining of coal for fuel increased, dramatically altering the sociomaterial landscape as it brought improvement for some, these once innovative practices faded into what was perceived as the homogenous fabric of rural traditionalism, gradually narrowing coal's recognized identity.

The historical trajectories that helped shape this development are vast and complex, as the daily use of coal, the political organization of mining and the classification of matter continued to be deeply entangled. Very briefly, a new series of coal-fired steam engines of the early nineteenth century began to allow for more efficient use of coal as fuel, making it an increasingly attractive power source in places where capital investment and access to coal converged - this last extended by expanding transport systems. This went hand in hand with increased consumption of coal as fuel in European industry, reinforced by contemporary industrial upscaling. In this context, the Compagnie des Mines d'Anzin quickly monopolized the resources to mine and sell French coal with the financial aid of Parisian private bankers and sustained governmental tariff protection..$^{73}$ As the uses of French coal were mounting, coal's recognized identity was both narrowed and generalized as fossil fuel. Meanwhile, at midnineteenth century, the fertile ashes once known as cendres de charbon de terre came to be referred to in purchase agreements and scientific textbooks as the very particular "cendres noires de Picardie". ${ }^{4}$

\section{Conclusion}

What, then, is coal? This essay provides at least two lessons that help answer this question in a historically meaningful way. The first takes us back to Timothy Mitchell's discussion of what he calls coal and oil's "socio-technical agencies."75 As powerfully insightful as his analysis is, he begins by classifying these substances as carbon fuels, thereby black-boxing their material identities - even

73 Geiger, Anzin Coal Company (see note 39).

74 Pierre, Chimie Agricole, pp. 489-49o (see note 5o); M. Andraud et al., Dictionnaire du commerce et des marchandises, vol. 1 (Paris: Guillaumin, 1837), 495; A. Payen et A. Richard, D'Agriculture théorie et pratique a l'usage des écoles d'agriculture, des propriétaires et des fermiers, vol. 1 (Paris: Hachette, 1851), 38-39.

75 Timothy Mitchell, Carbon Democracy, pp. 12-42 (see note 3). 
as he integrates them in his analysis. By including the material character of coal in the historically evolving mix out of which its identity flows, this essay suggests the interpretive fecundity of recognizing that agency is at once social, technical and material. By mutually informing each other through time, these three aspects constitute an entity's historically evolving identity. Coal was not always already a carbon fuel, leading ineluctably to the socio-technical promises and threats of the industrial world. Rather, its identity evolved over time through interaction with and use of its embodied properties (themselves quite situational in character) in the field, the laboratory and the workshop, on the printed page, in the marketplace, courts and legislative assemblies.

This first lesson thus responds to a broad tendency to consider a substance's identity as providing a source of historical explanation, based on its purportedly ahistorical character. The argument made here is that this is precisely what needs to be investigated because the entwinement of the material with the social and the technical renders identity innately historical. The second lesson relates to the historical consideration of substances as commodities. This essay illustrates the struggles entailed in transforming coal from an inchoate field of confusedly classified material substances into more clearly identified and regulated substances liable to profitable excavation and exploitation. So too does it document contestations and alternatives. In doing so, it reminds us that considering substances such as coal as 'resources' should not be done in a narrow economic sense. ${ }^{76}$ Neither is it warranted to focus narrowly on the historical links between material 'resources' such as coal and the technological contrivances with which they were processed and put to use. In both these cases, a further step often involves speaking of 'human capital' whereby people, along with their knowledge and skill are viewed as one more set of resources that contributed to economically measured productivity. This essay has instead shown how human actors and the socio-material networks in which they were engaged sometimes worked toward goals other than economic progress for its own sake, oeconomically seeking to steward human and material 'resources' in ways that benefited both nature and society. Given that concerns with the combined economic and environmental crises we currently face have led to paying increased attention to the era covered by this essay and volume of which it is a part - viewing it as the birthplace of modern industrialization, environmental decline and socio-geographical inequalities - recognizing the past existence of such alternatives might prove salutary as we plan for our future.

76 Lissa Roberts, "Producing (in) Europe and Asia, 1750-1850," Isis 106 (2015): 857-865. 
TABLE 2.1 Coal mines exploited for fertilizers ("des mines de terre de houille")

\begin{tabular}{|c|c|c|c|c|}
\hline 5 & Location & Opened in* & Region & Source \\
\hline 1 & Beaurain & 1753 & Picardy, Aisne & $\begin{array}{l}\text { A, p. } 265 \\
\text { B, p. } 546 \\
\text { E, p. } 44 \\
\text { J, p. } 15 \\
\text { K, p. } 395 \\
\text { N, p. } 95 \\
\text { O, p. } 5^{24-25} \\
\text { P, p. } 185\end{array}$ \\
\hline 2 & $\begin{array}{l}\text { Suzy, Faucoucourt, } \\
\text { Cessieres and Lizy }\end{array}$ & $175^{6}$ & Picardy, Aisne & $\begin{array}{l}\text { A, p. } 265 \\
\text { B, p. } 546 \\
\text { E, p. } 44,55 \\
\text { I, p. } 68 \\
\text { P, p. } 185 \\
\text { R, p. } 28 \\
\text { T, p. } 374\end{array}$ \\
\hline 3 & Armay & $175^{\circ \mathrm{os}}$ & Picardy, Aisne & B, p. 545 \\
\hline 4 & Annoy and Rumigny & 1760 & Picardy, Somme & $\begin{array}{l}\text { A, p. } 265 \\
\text { B, p. } 545 \\
\text { E, p. } 44 \\
\text { I, p. } 67 \\
\text { J, p. } 15 \\
\text { P, p. } 185\end{array}$ \\
\hline 5 & Jussy & 1760 & Picardy, Aisne & $\begin{array}{l}\text { I, p. } 67 \\
\text { J, p. } 15 \\
\text { O, p. } 524-25 \\
\text { P, p. } 185 \\
\text { R, p. } 28\end{array}$ \\
\hline 6 & Hinacourt & 1760 & Picardy, Aisne & $\begin{array}{l}\text { I, p. } 67 \\
\text { J, p. } 15\end{array}$ \\
\hline 7 & Sissonne & 1761 & Picardy, Aisne & I, p. 65-66 \\
\hline 8 & Anvi and Montigny & $1753^{-1761}$ & Picardy, Amiens & $\begin{array}{l}\text { C, p. } 186 \\
\text { D, p. } 195 .\end{array}$ \\
\hline 9 & Villé and Breuil & 1762 & Bas-Rhin & $\begin{array}{l}\text { I, p. } 65 \\
\text { R,p. } 28\end{array}$ \\
\hline
\end{tabular}


TABLE 2.1 Coalmines exploited for fertilizers (“des mines de terre de houille”) (cont.)

\begin{tabular}{|c|c|c|c|c|}
\hline 5 & Location & Opened in* & Region & Source \\
\hline 10 & Itancourt & 1767 & Picardy, Aisne & $\begin{array}{l}\text { E, p. } 44 \\
\text { G, p. } 407 \\
\text { I, p. } 67 \\
\text { R, p. } 28\end{array}$ \\
\hline 11 & Vendeuil & 1769 & Picardy, Aisne & $\begin{array}{l}\text { E, p. } 44 \\
\text { I, p. } 67 \\
\text { P, p. } 185 \\
\text { R, p. } 28\end{array}$ \\
\hline 12 & Homblières & 1771 & Picardy, Aisne & $\begin{array}{l}\text { E, p. } 44,69 \\
\text { G, p. } 407 \\
\text { I, p. } 67\end{array}$ \\
\hline 13 & Beaurieux & 1772 & Picardie, Aisne & $\begin{array}{l}\text { F, p. } 404 \\
\text { I, p. } 65 \\
\text { T, p. } 374\end{array}$ \\
\hline 14 & Travecy & $1753^{-177^{2}}$ & Picardy, Aisne & $\begin{array}{l}\text { B, p. } 546 \\
\text { H, p. } 216 \\
\text { R, p. } 28 \\
\text { E, p. } 44 \\
\text { I, p. } 67 \\
\text { P, p. } 185\end{array}$ \\
\hline 15 & $\begin{array}{l}\text { Rheims (direction } \\
\text { Soissons) }\end{array}$ & $1753^{-1772}$ & Marne & $\begin{array}{l}\text { E, p. } 45 \\
\text { Q, p. } 357\end{array}$ \\
\hline 16 & Canly & 1775 & Picardy, Oise & $\begin{array}{l}\text { N,p. } 95 \\
\text { O, p. } 524\end{array}$ \\
\hline 17 & Baurin & $1753^{-1775}$ & Picardy, Somme & $\begin{array}{l}\text { F, p. } 397 \\
\text { G, p. } 407\end{array}$ \\
\hline 18 & Chavignon & $1753^{-1776}$ & Picardie, Aisne & $\begin{array}{l}\text { E, p. } 44,69 \\
\text { F, p. } 403\end{array}$ \\
\hline 19 & La Fère / Charmes & 1777 & $\begin{array}{l}\text { Picardy, } \\
\text { Aisne }\end{array}$ & $\begin{array}{l}\text { B, p. } 546 \\
\text { I, p. } 68 \\
\text { P, p. } 185 \\
\text { R, p. } 28\end{array}$ \\
\hline 20 & $\begin{array}{l}\text { Mezy-Moulins and } \\
\text { Passy-sur-Marne }\end{array}$ & 1779 & Picardy, Aisne & $\begin{array}{l}\text { E, p. } 45,54,69 \text {, } \\
72,211 \\
\text { I, p. } 64 \\
\text { R, p. } 28 \\
\text { T, p. } 374\end{array}$ \\
\hline
\end{tabular}




\begin{tabular}{|c|c|c|c|c|}
\hline 5 & Location & Opened in* & Region & Source \\
\hline 21 & Mailly & $1753^{-1780}$ & Picardy, Somme & $\begin{array}{l}\text { B, p. } 546 \\
\text { E, p. } 44,69-70\end{array}$ \\
\hline 22 & Golancourt & $1753^{-1780}$ & $\begin{array}{l}\text { Picardy, } \\
\text { Oise }\end{array}$ & $\begin{array}{l}\text { B, p. } 546 \\
\text { E, p. } 44 \\
\text { O, p. } 5^{24-25} \\
\text { P, p. } 185\end{array}$ \\
\hline 23 & Liez & $1753^{-1780}$ & Picardie, Aisne & $\begin{array}{l}\text { B, p. } 546 \\
\text { E, p. } 44 \\
\text { I, p. } 67 \\
\text { P, p. } 185\end{array}$ \\
\hline 24 & Luzancy & $1753^{-1780}$ & $\begin{array}{l}\text { Brie, Seine-et- } \\
\text { Marne }\end{array}$ & $\begin{array}{l}\text { E, p. } 43,54,102 \text {, } \\
118\end{array}$ \\
\hline 25 & Marlemont & $1753^{-1780}$ & $\begin{array}{l}\text { Champagne, } \\
\text { Ardennes }\end{array}$ & E, p. $41,45,118$ \\
\hline 26 & Aubigny & $1753^{-1780}$ & Picardy, Somme & E, p. $41,45,118$ \\
\hline 27 & Ecogne & $1753^{-1780}$ & $\begin{array}{l}\text { Champagne, } \\
\text { Ardenne }\end{array}$ & E, p. 118 \\
\hline 28 & $\begin{array}{l}\text { bois de Prie } \\
\text { (Mésières) }\end{array}$ & $1753^{-1780}$ & $\begin{array}{l}\text { Champagne, } \\
\text { Ardenne }\end{array}$ & E, p. $41,45,118$ \\
\hline 29 & Muirancourt & $1753^{-1780}$ & Picardy, Oise & $\begin{array}{l}\text { E, p. } 44,71 \\
\text { K, p. } 395 \\
\text { O,p. 524-25 }\end{array}$ \\
\hline 30 & Beuvraignes & $1753^{-1780}$ & Picardy, Somme & $\begin{array}{l}\text { E, p. } 44 \\
\text { O,p. 524-25 }\end{array}$ \\
\hline 31 & Benet & $1753^{-1780}$ & & E, p. 44 \\
\hline 32 & Thiérache & $1753^{-1780}$ & Picardy, Aisne & E, p. 45 \\
\hline 33 & Rocroi & $1753^{-1780}$ & $\begin{array}{l}\text { Champagne, } \\
\text { Ardenne }\end{array}$ & $\begin{array}{l}\text { E, p. } 45,55,118, \\
212\end{array}$ \\
\hline 34 & Saint-Aude & $1753^{-1780}$ & & $\begin{array}{l}\text { E, p. 90, 104, } \\
118\end{array}$ \\
\hline 35 & Vandeuil & $1753^{-1783}$ & $\begin{array}{l}\text { Champagne, } \\
\text { Marne }\end{array}$ & B, p. 546 \\
\hline 36 & Bassay & $1753^{-1783}$ & & B, p. 546 \\
\hline 37 & Hinnacourt & $1753^{-1783}$ & Picardy, Oise & B, p. 546 \\
\hline 38 & Lambays & $1753^{-1783}$ & & B, p. 546 \\
\hline 39 & Le Santerre & $1753^{-1783}$ & Picardie, Somme & B, p. 546 \\
\hline
\end{tabular}


TABLE 2.1 Coalmines exploited for fertilizers (“des mines de terre de houille”) (cont.)

\begin{tabular}{|c|c|c|c|c|}
\hline 5 & Location & Opened in* & Region & Source \\
\hline 40 & Roye & $1753-1783$ & Picardie, Somme & $\begin{array}{l}\text { B, p. } 546 \\
\text { M, p. } 827-28\end{array}$ \\
\hline 41 & Chaulnes & $1753^{-1783}$ & Picardie, Somme & B, p. 546 \\
\hline 42 & Rollot, Montdidier & $1753-1783$ & Picardie, Somme & $\begin{array}{l}\text { B, p. } 546 \\
\text { O, p. } 524 \\
\text { T, p. } 374\end{array}$ \\
\hline 43 & Verberie & $1753^{-1783}$ & Picardie, Oise & $\begin{array}{l}\text { B, p. } 546 \\
\text { L, p. } 20 \\
\text { O, p. } 5^{2} 5\end{array}$ \\
\hline 44 & Compiègne & $1753-1783$ & Picardie, Oise & $\begin{array}{l}\text { B, p. } 546 \\
\text { N, p. } 95 \\
\text { O, p. } 524 \\
\text { T, p. } 374\end{array}$ \\
\hline 45 & Benay & $1753^{-1787}$ & Picardy, Aisne & $\begin{array}{l}\text { I, p. } 67 \\
\text { P, p. } 185\end{array}$ \\
\hline 46 & Urcel & $1753^{-1796}$ & Picardy, Aisne & I, p. $63-64,66$ \\
\hline 47 & Mesnil-Saint-Laurent & $1753^{-1796}$ & Picardy, Aisne & I, p. 67 \\
\hline 48 & Hallencourt & $1753^{-1796}$ & Picardy, Somme & I, p. 67 \\
\hline 49 & Cerisy & $1753^{-1796}$ & Picardy, Somme & I, p. 67 \\
\hline $5^{0}$ & Lisfontaine & $1753^{-1796}$ & Picardy, Oise & I, p. 67 \\
\hline $5^{1}$ & Gibercourt & $1753-1796$ & Picardy, Oise & I, p. 67 \\
\hline $5^{2}$ & Eaucourt & $1753^{-1796}$ & Picardy, Somme & I, p. 67 \\
\hline 53 & Cugny & $1753^{-1796}$ & Picardy, Aisne & I, p. 67 \\
\hline 54 & Blérancourt & $1779-1796$ & Picardy, Aisne & $\begin{array}{l}\text { I, p. } 68 \\
\text { T, p. } 374\end{array}$ \\
\hline 55 & Arsy & $1775^{-1812}$ & Picardy, Oise & $\begin{array}{l}\text { N, p. } 95 \\
\text { S, p. } 108\end{array}$ \\
\hline $5^{6}$ & Jonquières & $1775^{-1812}$ & Picardy, Oise & N, p. 95 \\
\hline 57 & Moyvillers & $1775^{-1812}$ & Picardy, Oise & N, p. 95 \\
\hline $5^{8}$ & $\begin{array}{l}\text { Remy, Estrées-Saint- } \\
\text { Denis }\end{array}$ & $1775^{-1812}$ & Picardy, Oise & N, p. 95 \\
\hline
\end{tabular}

* When a source mentions a specific year of opening or concession for a mine, this year is listed in the table. Otherwise, the period in which the mine opened is estimated by reference to the earliest known source that cites the mine. 


\section{Sources}

A. De Méliand, Charles-Blaise. "Houille." In Diderot and d'Alembert, eds.,Encyclopédie, ou Dictionnaire raisonné des sciences, des arts et des métiers, vol. 8, 265-68 (Paris: Briasson, 1766).

B. De la Platière, Roland. "Abrégé historique de l'usage des cendres de tourbes superficielles \& souterreines pour fertiliser les terres en Hainaut \& dans la haute Picardie," Art du Tourbier, in J.E. Bertrand, Descriptions des arts et métiers, faites ou approuvées par Messieurs de l'Académie royale des sciences, nouvelle édition, vol. XIX (Neuchatel: L'Imprimerie de la Société Typographique, 1783), 472-565.

C. Duhamel du Monceau, Henri-Louis. Éléments d'agriculture (Paris: Guerin and Delatour, 1762).

D. Duhamel du Monceau, Henri-Louis. Traité de la culture des terres. Vol 6. (Paris: Guerin and Delatour, 1761).

E. Perthuis de Laillevault, Léon. Expériences et nouvelles observations sur les Houilles d'engrais and Recherches sur la houille d'engrais et les houilleres (La Haye: Clousier et Jombert, 1780).

F. Dictionnaire minéralogique et hydrologique de la France. Vol. 4 (Paris: Brunet, 1776).

G. Review of Raulin, Joseph. "Examen de la houille, considérée comme engrais des terres", Journal Encyclopédique. Vol. 6 (Bouillon, 1775), 406-418.

H. Courier du Bas-Rhin 1772.

I. Suite du Tableau des Mines et Usines de la France," Journal des Mines. No. 25 (1796): 49-73.

J. $\quad$ Brayev, B.L., Statistique du département de l'Aisne (Laon: Melleville, 1825).

K. Journal des mines, ou recueil de mémoires sur l'exploitation des Mines, et sur les Sciences et les Arts qui s'y rapportent. Vol. 12 (Paris: Bossange, Masson et Besson, 1801).

L. Grave, Louis. Précis statistique sur le canton de Pont-S. ${ }^{T E}$-Maxence, arrondissement de Senlis (Oise) (1843).

M. Tessier, Alexandre-Henri. Encyclopédie méthodique: Agriculture. Vol. 2 (Paris: Panckoucke, 1791).

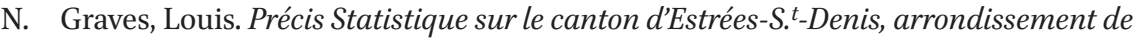
Compiègne (Oise.) (1832).

O. De la Platiere, Roland. Art du Tourbier, in J.E. Bertrand, Descriptions des arts et métiers, faites ou approuvées par Messieurs de l'Académie royale des sciences, nouvelle édition, vol. XIX (Neuchatel: L'Imprimerie de la Société Typographique, 1783), 471-558.

P. Monnet, Antoine-Grimoald. "Memoire Sur la Terre pyriteuse qui se trouve en Picardie \& dans le Soissonnois, \& sur les moyens qu'il y a d'établir des Fabriques de Vitriol avec cette matiere", in Rozier, ed. Observations sur la physique, sur l'histoire 
naturelle et sur les arts. Vol. 11 (Paris: Bureau du Journal de Physique, 1778), 183-186.

Q. Dictionnaire minéralogique et hydrologique de la France. Vol. 2, no. 2 (Paris: Costard, 1772).

R. Statistique générale et particulière de la France et de ses colonies (Paris: Buisson, 1804).

S. Graves, Louis. Précis statistique sur le canton de Liancourt, arrondissement de Clermont (Oise) (1837).

T. Cuvier, F.G., ed. Dictionnaire des Sciences Naturelles, vol. 26 (Strasbourg: Levrault, 1823). 